DANIELA TOŠEVA

UDC: $726.82: 347.65 / .68-055.2(37)(093)$

ISU "Gavrilo Romanovich Derzhavin"

726.82:347.62-055.2(37)(093)

Sveti Nikole - Bitola

toshevadaniela@gmail.com

\title{
TESTAMENTI FACTIO OF WOMEN IN TWO FUNERARY ORATIONS
}

\begin{abstract}
Two funerary orations made in honor of Roman matrons are considered in this paper: the Laudatio Turiae and the Laudatio Murdiae. The epitaphs belong to the Augustan period and are very indicative on hereditary rights of women in a specific period of Roman history. I discuss the legal term testamenti factio and investigate its broad meaning and implications in the two orations. These women, as they are seen from male perspective, were quite capable of managing their own property and affairs, by using the benefits of the laws. However, their lives were exceptional, and cannot be used to make generalization about the female population in Rome, mainly because they belong to the upper echelons of the Roman society.
\end{abstract}

\section{Laudationes funebris in honor of women}

Delivery of a speech praising the virtues of the deceased was a usual part of the Roman funeral ceremony, and this is supported by great deal of evidence, primary and secondary. These speeches were made in honor of illustrious men and were delivered publicly from the rostra, whether the funeral was public or private. Their structure is approximately the same, covering specific areas of achievements, which are generalized by the following virtues, according to Hugh Lindsay: ${ }^{1}$ military reputation, capacity in public speaking, success in public life, honorable financial success, and good fortune in leaving successors. This kind of commemoration for the predecessors was expected from the upper-class families. ${ }^{2}$

${ }^{1}$ H. Lindsay, 2004, 89-90.

${ }^{2}$ Cicero informs that these accomplishments were sometimes fabricated (Cic. Brut. 62.): Et hercules eae quidem exstant: ipsae enim familiae sua quasi ornamenta ac monumenta servabant et ad usum, si quis eiusdem generis occidisset, et ad memoriam laudum domesticarum et ad illustrandam nobilitatem suam. quamquam his laudationibus historia rerum nostrarum est facta mendosior. multa enim scripta sunt in eis quae facta non sunt: falsi triumphi, plures consulatus, genera etiam falsa et ad plebem transitiones, cum homines humiliores in alienum eiusdem nominis infunderentur genus; 
Women, on the other hand, were expected to have less or no achievements in the public life, and much more in the family life. This is confirmed in the literature and the epigraphic sources as well. Three Latin funerary orations are preserved in honor of women, all of whom are examples of typical matronae Romanae: Laudatio Turiae, ${ }^{3}$ Laudatio Murdiae, ${ }^{4}$ and Laudatio Matidiae. ${ }^{5}$ The first two orations belong to the Augustan Principate (r. 27 BC to AD 14), and the third one is written during Hadrian's rule (r. AD 117 to 138). It is obvious from the text of the eulogies that they were not delivered from the rostra, ${ }^{6}$ but among close family and friends at the funeral pyre (tomb). These women are praised for their devotion to family life and their good virtues, which are expected qualities of Roman matrons. Their male virtues such as virtus ("courage"), patientia ("endurance"), firmitas animi ("strength"), and constantia ("steadfastness"), as Emily A. Hemelrijk ${ }^{7}$ shows, is what makes them exceptional; however, other literary texts have demonstrated that the capacity of women in the areas of men, is to their demise if they lack pudicitia ("sexual morality") and modestia ("modesty"), typical feminine features. ${ }^{8}$

The orations that are examined in this paper are Laudatio Turiae (LT) and Laudatio Murdiae (LM), because of their temporal proximity and the data they provide on hereditary rights, marriage and family. The Laudatio Matidiae is exempted, because the laws on inheritance and marriage were slightly changed at the beginning of the second century AD. ${ }^{9}$ So, the main interest in these two orations is the active and passive testamenti factio ${ }^{10}$ of women in the late Republic and early Principate. Roman jurists knew about testamenti factio which had

"Die freilich, beim Herakles, bleiben erhalten: die Familien selbst pflegen sie zu hüten, als Ehrenurkunden, sei es zum Gebrauch, falls jemand aus der Sippe sterben sollte, sei es zur Erinnerung an die Ruhmestaten ihres Hauses, sei es zur Verherrlichung ihrer vornehmen Abstammung. Nur: durch diese Lobreden ist unsere Geschichtsschreibung verfälscht worden. Vieles findet sich da niedergeschrieben, was nie geschehen ist: falsche Triumphfeiern, zahlreichere Konsulate, ja sogar falsche Genealogien und Ubertritte in den Plebejerstand, indem eben Männer von niedrigerer Abstammung sich in ein fremdes Geschlecht desselben Namens eindrängten.” (transl. Bernhard Kytzler, 2000)

${ }^{3}$ CIL VI 1527, 31670, $37053=$ ILS 8393.

${ }^{4}$ CIL VI $10230=$ ILS 8394.

${ }^{5}$ CIL XIV 3579: Dessau = Inscr. It. IV 1,77: Mancini. The epigraphic text is not preserved, but reconstructed on the basis of four transcriptions made in the $16^{\text {th }}$ century.

${ }^{6}$ This is not certain for the Laudatio Matidiae.

${ }^{7}$ Emily A. Hemelrijk, 2004, 185-197.

${ }^{8}$ Cf. Fulvia who was in succession wife of P. Clodius Pulcher, C. Scribonius Curio, and M. Antonius.

${ }^{9}$ The Laudatio Murdiae is a eulogy delivered by the emperor Hadrian in honor of his mother in law, Matidia in AD 119/120.

${ }^{10}$ The non-Roman term testamemti factio activa et passiva will not be used in this paper, because it is unknown as such in Roman law and is misleading. 
several meanings: (1) the capacity to inherit; ${ }^{11}$ (2) the capacity to compose will ${ }^{12}$; (3) the legal capacity of being a witness to a will. ${ }^{13}$ The inheritance rights of women, specifically the active testamenti factio, are examined in detail in $L M$, while $L T$ provides more information on family status of women and passive testamenti factio. The examination will start with $L T$ because it is chronologically justified and because the passive testamenti factio was the only hereditary capacity that women had according to ius civile.

\section{THE LAUDATIO TURIAE: PASSIVE TESTAMENTI FACTIO}

The Laudatio Turiae is the longest Latin inscription erected by a private individual. Theodor Mommsen attributed the epitaph to Q. Lucretius Vespillo, consul in $19 \mathrm{BC}$, and his wife Turia, ${ }^{14}$ but the identity and hence the name of the laudata are disputed today. The identification of the laudator and the laudata is insignificant for this research, yet for the sake of convenience, in this paper the conventional name Turia will be used for the laudata.

The laudator is the husband of the deceased woman, Turia, with whom he was married for 41 years. ${ }^{15}$ He doesn't speak of her, but speaks to her; he addresses her directly in second person, instead of speaking of her in third person, which is more conventional. He praises her eventful and virtuous life, as well as her devotion to him since the very beginning of their marriage. The events are narrated chronologically, revealing her virtues and achievements. ${ }^{16}$ They married in 47 or $49 \mathrm{BC}$, and the woman died in 7 or $6 \mathrm{BC}$. They lived in a turbulent period of the Roman history, the triumviral period (43-31 BC) which is characterized by the Civil war, political crisis and socioeconomic transformations, events that affected this family adversely. At the beginning of the eulogy the husband informs that before their wedding day ("ante nuptiarem diem", $L T$ col. I. 3) (it's unknown how long before the wedding day), Turia's parents were killed at the country site, in their villa rustica. She was soon left alone to deal with the conse-

11 "heredes institui possunt, qui habet testamenti factionem cum testatore" ("Those can be appointed heirs who have a capacity to make a will with the testator.") (Tit. Ulp. XXII.1.)

12 "si quaeramus an valeat testamentum, imprimis advertere debemus an is qui id fecerit habuerit testamenti factionem" ("in considering whether a will is valid, we must first ascertain whether its maker had the capacity to make it") (Gai. Inst. II. 114)

13 "nec testis ad testamentum adhiberi poterit, cum neque testamenti factionem habeat." ("he should also be unable to be used as a witness to a will, as he has not testamenti factio") (Dig. 28.1.18)

${ }^{14} \mathrm{~T}$. Mommsen, $1863,455-489$.

${ }^{15}$ The text is broken here, and it could be simply XXXI instead of XXXXI. However, the narrative in the eulogy suggests the latter.

${ }^{16}$ The chronology of the events made by Osgood (2014) is quite acceptable and will be used in this paper. 
quences and the revenge of her parents, because her husband (more probably fiancé then) went to Macedonia, and her sister's husband, whose name is revealed as Cluvius, was sent on duty to Africa. She managed to honor her father's will, despite the difficulties imposed on her by a third party. ${ }^{17}$ During their life together she saved her husband's life, who was probably among the proscribed. She managed to prepare a safe hiding place for him, and she begged for his life while he was away. After the period of political unrest they settled down and enjoyed eventually, but weren't lucky enough to conceive children. Turia offered her husband to divorce her, and to remarry for the sake of begetting children. ${ }^{18}$ This was the period when the Augustan legislation on marriage and childbearing promotion started to evolve. Turia's husband didn't take her offer: "I could never have assented to your proposal without bringing great shame upon me and unhappiness on both of us." $" 19$ (col. II. 46-47).

The first part of the eulogy is important for this research and it will be examined in detail. Three women are mentioned in the text: Turia, her mother and her sister. They were Roman citizens, likely from the equestrian order, and probably had different family status (or caput $^{20}$ ) at some point.

\section{The coemptio of the mother and breaking the will}

After Turia's parents were killed, as previously noted, a third party tried to break the will of her father, to proclaim it void: "There was an attempt to make both you and your sister recognize the will, in which we were heirs, was broken, because of the coemptio your father made with his wife." ${ }^{21}$ ( $L T$ col. I. 13-14). If the third party succeeded in their attempt, Turia would have become sole heiress of her father's property - she would have inherited ab intestato, excluding her sister.

${ }^{17}$ The names of these people are not disclosed, because they are of no importance for the eulogy; it is only revealed that they weren't from the same clan (gens) as Turia ( $L T$ col. I.24).

${ }^{18}$ The wife's sterility was a legal cause for divorce.

${ }^{19}$ The translation of the excerpts from $L T$ is by Osgood, 2014.

"neque enim cedere tibi sine dedecore meo et communi infelicitate poteram."

20 "Caput" in Roman law refers to "legal capacity", which is different from "persona", denoting "a human being". Every free person under the protection of the Roman law is denoted generally by the term caput or status, which has three elements: the status of liberty, of citizenship and of family. Regarding the status of family, though, a person could be alieni iuris (who is a subject to the right of someone else, i.e. pater familias) and sui iuris (independent person, such as pater familias, the emancipated children, the woman in sine manu marriage). The change of the personal status, i.e. caput with all three elements, is named capitis deminutio. The smallest change, the capitis deminutio minima is a legal institute which is based on the change of the family, and hence change on the status inside the family (alieni iuris or sui iuris).

21 "Temptatae deinde estis ut testamen[tum,] quo nos eramus heredes, ruptum diceretur coemptione facta cum uxore." 
The argument of the third party to break the will was the coemptio her father made with her mother. Let us first see what coemptio means in this case.

Gaius speaks about coemptio (Inst. I. 108-115b), when discussing persons who are in manu (hand, marital power). In the past, from Gaius perspective, women passed into manus by entering in one of the three forms of valid marriage: confarreatio, usus and coemptio. Therefore, the first purpose of coemptio was matrimonial (matrimonii causa). The process itself, as Gaius informs, was an adaptation of mancipatio, which means it was solemn. The result of this process of fictional buying is a manus marriage, i.e. a marriage where the woman is under her husband authority, and is in a position of a daughter. The woman de facto changes her family status when entering a marriage this way. There are also fiduciary purposes (fiduciae causa) for making a coemptio. This happens when a woman wants to evade a tutorship: a woman sui iuris makes coemptio tutore auctore (with her tutor's auctoritas) with some man of her choice, usually in order to make a will. ${ }^{22}$ The man that she chooses emancipates her and she becomes sui iuris again and the coemptionator becomes her tutor fiduciarius, which means tutor pro forma. So, this type of coemptio was of importance for active testamenti factio which is addressed in the next section. The purpose of coemptio was indicated in the pactum fiduciae. If the coemptionator was her husband, and the purpose of the coemptio was not matrimonial but fiduciary, as it is probably in this particular case, the woman would become filiae loco to him, as if she was his daughter, i.e. she is under his power (manus): "Uxor quoque, quae in manu est, ei cuius in manu est sua heres est, quia filiae loco est."23 ("A wife in manus is also a sua heres to the man in whose manus she is, since she is in the position of a daughter"). The will which is disputed in $L T$ belonged to Turia's father, besides there is no mention of a will made by her mother, so we must assume that the purpose of the coemptio was not making a will. ${ }^{24}$ Also, we must exclude coemptio for matrimonial purposes, because it doesn't make the will invalid. But changing the status of a family member, or birth to another member in the meantime, after the will making, is a reason for breaking the will.

${ }^{22}$ Olim etiam testamenti faciendi gratia fiduciaria fiebat coemptio. tunc enim non aliter feminae testamenti faciendi ius habebant, exceptis quibusdam personis, quam si coemptionem fecissent remancipataeque et manumissae fuissent. (Gai. Inst. I. 115a)

"Formerly too fiduciary coemptio used to be performed for the purpose of making a will. This was at a time when women, with certain exceptions, had not the right to make a will unless they had made a coemptio and had been remancipated and manumitted." (transl. De Zulueta)

${ }^{23}$ Collatio 16.2.3 (Gaius, Institutiones 3.3)

${ }^{24}$ There is another type of coemptio, not mentioned by Gaius like the previous, but by Cicero. This type was used when "the woman wanted to get rid of sacra (family cult) with which she was burdened." See de Zulueta, 1963, 36. 
According to Ulpian, a will can be broken in two ways (Tit. Ulp. XXIII. 1-4):

"(1) A will that was legally made is invalidated in two ways: if it is broken or rendered ineffectual. (2) A will is broken by (subsequent) change, that is, if another will is legally made; and also by accession (of subsequent sui heredes), that is, if a suus heres accedes who is neither instituted an heir nor disinherited as is required." 25

"A will is invalid if it does not either institute a suus heres as heir or disinherit him. Therefore, the rules for intestate succession came into play." ${ }^{26}$ And in Roman law, testamentary and intestate succession excluded one another. The will of Turia's father was actually void when his wife changed her status for whatever reasons she had. This is probably the reason why the third party wanted to break the will. However, Turia didn't let that happen, but it is not clear on what grounds she did that.

\section{Sua heres, sui iuris and tutor legitimus}

Turia, according to the law, became sui iuris after her father's death, because she was sua heres, actually the only sua heres, a legal term which refers to the person who was under patria potestas at the time of death of pater familias. Legally sui heredes were the first heirs (primo gradu), and they took the hereditas in equal shares. In Turia's case it means that the whole property of her father would go to her if the will was void. The people that tried to break the will had this in mind - to impose tutela legitima on Turia, to administrate her property, and become the sole heirs of her. Tutor legitimus is appointed according to Lex XII Tab. V.6, when there is no tutor testamentarius, i.e. tutor appointed by will: "To persons for whom a guardian has not been appointed by will, to them, by the Law of the Twelve Tables, agnates are guardians." ${ }^{27}$ She succeeded in saving the will because they gave up and because they were not her agnates, in fact, as the husband informs: "those who were bringing action had no such right, since they were not members of the same clan." ${ }^{28}$ The duty of tutor legitimus can be taken only by someone from the closest agnates (proximi agnati) that Turia didn't have. Therefore, she had the choice to acknowledge

${ }^{25}$ Tansl. by B. Frier and T.A.J. McGinn, 2004.

“(1) Testamentum iure factum infirmatur duobus modis, si ruptum aut inritum factum sit. (2) Rumpitur testamentum mutatione, id est si postea aliud testamentum iure factum sit. Item agnatione, id est, si suus heres agnascatur, qui neque heres institutus neque ut oportet exheredatus sit."

${ }^{26}$ B. Frier and T.A.J. McGinn, 2004, 330.

${ }^{27}$ Transl. Remains of Old Latin, 1938. tores."

"Quibus testamento ... tutor datus non sit, iis ex Lege XII Tabularum agnati sunt tu-

${ }^{28}$ (23) [...] tamen iis qui intenderent non esse id (24) ius, quia gentis eiusdem non essent. 
the will, or to accept the inheritance as intestate, without tutor. She chose the former to honor her husband and her sister.

\section{The sister without testamenti factio}

Now, why Turia was the sole heiress ab intestato if she had a sister? Her sister could not have inherited intestate because she entered a marriage cum manu: "your sister would be cut out of the inheritance altogether, because she had come under the manus of Cluvius." 29 Her sister changed her family status, as their mother, with the mancipation (she was given to Cluvius in manu, conventio in manu) and she had no claim to the inheritance. She was filiae loco in another agnate family - that of her husband Cluvius, and had broken the family ties with her previous agnate family.

\section{Turia's husband as heir to his future father in law}

How Turia entered her marriage is unknown, whether she was with manus or not. She managed to validate the will of her father according to which heirs were: Turia, her sister, and Turia's husband. It is unusual for the future husband to be appointed in the will of his father in law as heir. It would have been more appropriate if he was appointed as legatarius, and if the legatum ${ }^{30}$ was with condition (sub conditione); actually, if the dowry was given that way. Anyway, he tells the story from his side, and he names himself heres, not legatari$u s$, and the inherited property as hereditas, not legatum: "You defended our shared position by stating the facts: the will had not been broken, with the result that each of us should hold onto our inheritance rather than having you alone taking the possession of the whole estate. It was your firm intention to uphold the acts of your father, so much so that even if you did not win the case, you insisted that you would share the inheritance with your sister." ${ }^{31}$ (LT col. I.18-20).

The sister and the mother certainly were alieni iuris. Turia after the death of her father became sui iuris, but what happened after entering the marriage is unknown, because there aren't any indications in the text. All three women had the capacity to inherit by will, the problem was the will itself, made before the coemptio of the mother. The difference between the women in succession law is when intestate succession became possible way of distributing the property, because they Cluvio."

29 "sorore omnino illius hereditatis (16) fore expertem, quod emancupata esset

${ }^{30}$ Legatum is a part of the inheritance, which the testator gives out of it from the heir ( $a b$ herede). If there is no heir, there is no legatum.

31 "(18)Veritate caussam communem tutata es: testamentum ruptum non esse ut uterque potius (19) hereditatem teneremus quam omnia bona sola possideres; certa quidem sentential (20) te ita patris acta defensuram ut, si non optinuisses, partituram cum sorore te adfirmares;" 
belonged to different agnate families: Turia was her own family when her pater familias died, the sister was filiae loco with her husband Cluvius, the mother was dead, but became the main interference in the testamentary succession.

\section{THE LAUDATIO MURDIAE: ACTIVE TESTAMENTI FACTIO}

This oration is read and translated by Hugh Lindsay ${ }^{32}$, who also focuses on the domestic and legal elements and examines them with precision. ${ }^{33} L M$ has been dated on orthographical principles no later than the Principate of Augustus (27 BC - AD 14). The laudata is Murdia, a woman from the upper classes of the Roman society, most probably from the equestrian order, and the laudator is her son from the first marriage, whose name is unknown. The laudator speaks of her in third person, addressing the praesentes. The focus of this laudatio is Murdia's testamentary judgment (iudicium, consilium) regarding the property distribution among her heirs and her devotion to her husbands.

There is no developed narrative of her life, certainly not of events as in the $L T$, because this sepulchral inscription is shorter than $L T$ and not preserved in its entirety. It is certain that Murdia was not univira $^{34}$ - her first husband died, and left her with son and inheritance. She later married again and gave birth to other children: sons and daughter(s?). Her son, the laudator, praises not only her right judgment in property distribution: "She made all her sons equal heirs, after her daughter had been given a share." 35 (LM 4-5), but also the moral aspects of making the will. Through the will the testators generally expressed their opinion of the others involved, and as Bruce Frier and Thomas A.J. McGinn observe "writing will was considered a moral duty itself". ${ }^{36}$ The moral virtues that the laudator enumerates, are the following: modestia ("modesty"), probitas ("honesty"), pudicitia ("chastity"), obsequium ("obedience"), lanificium ("wool-working"), diligentia ("diligence"), and fides ("trustworthiness") (LM 28).

What makes her exceptional from her son's perspective are not the above enumerated virtues, but the following: "but not with intention that she might set me ahead of my brothers through some reproach against them, but mindful of my father generosity, she decided to return to me what she received from my patrimony through my father's

${ }^{32}$ H. Lindsay, 2004, 88-97.

${ }^{33}$ Lindsay's transcription and translation of the inscription will be used in this paper.

${ }^{34}$ Augustan laws encouraged widows to remarry, especially if they were in their childbearing years. The Roman ideal of univira and the Augustan laws were obviously in conflict.

35 "omnes filios aeque fecit heredes, partitione filiae data."

${ }^{36}$ B. Frier and T.A.J. McGinn, 2004, 343. 
decision. ${ }^{\prime 37}$ (LM 9-13). According to Roman law, her property should be distributed equally among her children if intestate. On the other hand, she could have owned property, only if she was sui iuris. Persons alieni iuris had no legal ownership over property. Women were not allowed to have property in a peculium ${ }^{38}$, as filii familias or slaves. Anyway, Murdia made testamentum, and that qualifies her as sui iuris, which also means that she entered a marriage sine manu.

She composed her will during the Principate of Augustus, and she had the following possibilities to do that:

(1) The right of (three) children (ius (trium) liberorum). Married freeborn men and women, as well as freedmen and freedwomen, who had the right of (three) children, were granted many privileges. Women in particular, had the capacity to conduct their own legal and economic transactions, including the capacity to make a will. This means that they were emancipated from "tutelage of women" (tutela mulierum), as Gaius (Inst. I, 145) notifies:

"Accordingly, when someone assigns testamentary tutor for his son and daughter, on attaining the age of puberty the son ceases to be under tutelage, but the daughter continues to be under tutelage; only under the lex Julia and Papia Poppaea, by the right acquired from having children, women are emancipated from tutelage."

Women with ius liberorum were exempted from the requirement to employ tutor in order to make will. Tutela legitima was abolished by Claudius, an institution which threatened to break Turia's will in the previous section. As Jane F. Gardner says: "For women not in tutela legitima, obtaining tutor's consent to a will became in effect a formality." 40

(2) Emancipation. Pater familias decided for this process and it was performed while he was alive. The result of the emancipation was change of the family status: filius/filia familas becomes sui iuris, i.e. head of their own family. This is a variation of mancipation process: for a son, three fictional sales were used to break patria potestas; and for all other children-in-power, one sale (Gai., Inst. I.132; Tit. Ulp. $\mathrm{X} .1)$. However, only mancipation was not enough for making a will the woman had to have tutor which brings us to the next possibility.

37 "neque ea mente quo me fratribus meis quom forum aliqua contumelia praeferet sed sed memor liberalitatis patris mei reddenda mihi statuit quae iudicio viri sui ex patrimonio meo cepisset ut ea ussu suo custodita proprietati meae restiturentur."

${ }^{38}$ Persons in (someone else's) power could not own property, while technically they had ownership over the property. The ius commercii belonged to the pater familias or the husband with patria potestas. The property of the persons in power is called peculium.

${ }^{39}$ Itaque si quis filio filiaeque testamento tutorem dederit et ambo ad pubertatem pervenerint, filius quidem desinit habere tutorem, filia vero nihilo minus in tutela permanet: tantum enim ex lege Iulia et Papia Poppaea iure liberorum a tutela liberantur feminae. (Gaius Inst. I, 145)

${ }^{40}$ Jane F. Gardner, 1986,168. 
(3) Coemptio with pactum fiduciae ${ }^{41}$. In pre-Augustan legislation, the woman, in order to make will, she must make coemptio - to cut the links with her previous agnate family in order to change her family status known as capitis deminutio minima and obtain fiduciary tutor (see previous section). The Gnomon of the Idios Logos, the version that was composed after Hadrian's rule, $B G U$ 5.1210, mentions this provision regarding women with Roman citizenship: "A Roman woman is not permitted to bequeath outside the so-called coemptio. A legacy left by a Roman woman to a Roman girl who was a minor, was confiscated." 42

All these possibilities suggest that Murdia was sui iuris, and that she probably entered in marriage sine manu. This implicate that her first marriage was sine manu as well. She obviously didn't have tutor legitimus, but either appointed formal tutor fiduciarius, or she had the ius liberorum, or had made coemptio, changing the status. But first of all, she was emancipated, or was simply sua heres when the father died, before entering her first marriage. The property that she obtained from the first husband was in usus, which was a personal servitude, the right to use another's property without a right to produce (fructus) of the thing. Normally usus was left as a legacy which it seems was the case with Murdia. It was usual for the husbands to make separate provisions for their wives in their wills, which is proven from the papyri evidence; they granted them usus and/or usufruct in all or part of the property. So, Murdia in her first marriage had passive testamenti factio - she inherited from her husband, on which grounds exactly it is unknown, and she probably got her dowry back, and in the second one, she fulfilled her active testamenti factio, by composing a will under unknown cicumstances (certainly legal), because stricto iure women alieni iuris had the position of a daughter in the family of her husband - filiae loco, and couldn't write a will. Most of the marriages during the Republic were cum manu, therefore the women were alieni iuris, and incapable of making a will. There were some women, who underwent the changing of their family status during the marriage with coemptio, or some who entered a marriage sine manu, i.e. were already emancipated by their alive father (pater familias).

Regarding the inheritance rights between the husband and the wife, the law presents us with a peculiarity, which is valid for the period when $L T$ and $L M$ were composed. The Gnomon of the Idios Logos (31) shares information on inheritance rights between husband and wife: "A Roman woman is permitted to leave her husband the tenth part of what she possesses; anything more is confiscated. ${ }^{43}$ The same

${ }^{41}$ See previous section on coemptio.

${ }^{42}$ Transl. Select Papyri, 1934.

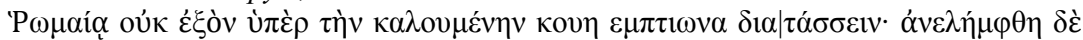

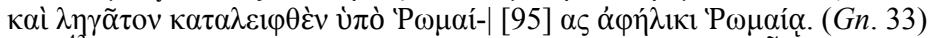

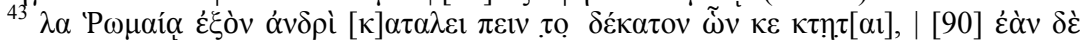
$\pi \lambda \varepsilon i_{0} v \alpha, \alpha \dot{\alpha} v \alpha \lambda \alpha \mu \beta \alpha ́ v \varepsilon[\tau \alpha 1]$. (Gn. Idios Logos, 31) 
rule, applied to both sexes, is declared in later text: Tit. Ulp. XV.1.: "Husband and wife may, under a will, take one tenth of the estate of either on account of marriage; but if either of them have surviving children by a previous marriage, he or she may, in addition to the tenth on account of marriage, take as many more tenths as there are children." ${ }^{44}$ This means that Murdia, if her first husband died intestate, inherited tenth part from his property, and another tenth for her son, which she now generously gives him back by means of will. Ulpian in Tit. XVI enumerates in which case the husband and the wife can inherit the whole property between them, and in which cases nothing. She might as well inherited the whole property, but we are not presented with the facts here, because it is of no importance to the eulogy.

Murdia was a woman with property that she obviously administrated herself, and had the freedom to distribute it at her please. However, Roman law was careful about leaving the property to extraneous people, and was very protective about the children. She was right regarding her children, and she accomplished that with the legal remedies at her disposal, not stricto iure, because she was a woman.

\section{Conclusion}

These sepulchral epitaphs had given a great deal of evidence on succession law regarding the upper classes, and especially on women's legal capacities related to inheritance and marriage status. The fact that "out of the fifty books of the Digest, eleven are occupied with the law of succession" 45 is indicative of the importance of succession law in Roman society.

The first oration $(L T)$ presents three women who lived at the end of the Republic and the beginning of the Principate. The monument is dedicated to Turia, who inherited a property from her father by will. However, the will was at danger to be broken, because her mother changed her status, and that made the will potentially invalid. If, the will of the father was broken, then Turia, with a status sui iuris after her father's death, would have become the sole heiress, with tutor legitimus, which was not a favourable position. Her sister was already married to a man named Cluvius and was emancipated to him. Automatically she changed her family status, because she entered another agnate family, where she was in a position of a daughter to her husband, provided he was the pater familias, as the epitaph suggests. So, she couldn't inherit intestate from her previous agnate family. Turia was

\footnotetext{
${ }^{44}$ Transl. Scott, available at https://droitromain.univ-grenoble-alpes.fr/Anglica/uipian scott.html\#XV

"Vir et uxor inter se matrimonii nomine decimam capere possunt. Quod si ex alio patrimonio liberos superstites habeant, praeter decimam, quam matrimonii nomine capiunt, totidem decimas pro numero liberorum accipiunt."

${ }^{45}$ John A. Crook 1967, 118.
} 
lucky, because those who asked the will to be broken and to impose a tutelage on her, were not her closest agnates. The details are unknown.

Regarding Murdia, she had almost full testamenti factio: she inherited from her first husband and married again and had a capacity to make a will. She could have done that only if she was sui iuris. Not only that, she had to have a tutor fiduciarius who is appointed by coemptio, or she had to have the ius liberorum. She must have been quite an independent woman herself, even if married twice and being mother to adult son(s).

The two women, Turia and Murdia, had property, and were from the equestrian order. Actually these remedies for alleviating their legal capacities were designed for women with property, and were directed toward the children. Nothing was a problem if the property was distributed to the children. There were restrictions only when the husband or extraneus was to inherit her property. Anyway, the general opinion is that in this period of Roman history, women started to gain more legal rights, a fact that is attested in papyri evidence, which is evident in these monuments, and it would become only better in the centuries that follow until the end of Justinian's reign.

\section{BIBLIOGRAPHY}

Berg, Ria. (ed.) The Material Sides of Marriage: Women and Domestic Economies in Antiquity. Institutum Romanum Finlandiae, Roma 2016.

Cicero, Marcus Tullius. Brutus. Lateinisch-deutsch Herausgegeben und übersetzt von Bernhard Kytzler. Artemis \& Winkler Verlag, Düsseldorf / Zürich, 2000.

Crook, John A. Law and Life of Rome. Cornell University Press, 1967.

De Zulueta, Francis. The Institutes of Gaius, Part I, Text with critical notes and translation. Oxford: Clarendon Press, 1958.

De Zulueta, Francis. The Institutes of Gaius, Part II: Commentary. Oxford: Clarendon Press, 1963.

Fowler, W. Waede. "On the New Fragment of the so-Called Laudatio Turiae" (C.I.L. VI.1527). The Classical Review, 19, (1905) 261-266.

Frier, Bruce, Tommas A.J. McGinn. A Case book on Roman Family Law. 2004.

Gardner, Jane F. Women in Roman law and society. Indiana University Press, 1986.

Hemelrijk, Emily A. "Masculinity and Femininity in the Laudatio Turiae". Classical Quarterly, 54.1 (2004), 185-197.

Horsfall, Nicholas. "Some Problems in the Laudatio Turiae". Bulletin of the Institute of Classical Studies, 1983, No. 30 (1983), 85-98. 
Iustinianus. Digesta Iustiniani 1-50 (The Digest of Justinian. Vols. 1-4, ed. T. Mommsen, P. Krüger, A. Watson, 1985.

Jones, Christopher P. A. "Speech of the Emperor Hadrian". The Classical Quarterly, May, 2004, 2, Vol. 54, No. 1 (May, 2004), 266-273.

Lindsay, Hugh. "The Laudatio Murdiae: Its Contents and Significance". Latomus, T. 63, Fasc. 1 (2004), 88-97.

Lowrie, Michele. Writing, Performance, and Authority in Augustan Rome. Oxford University Press, 2009.

Mantzilas, Dimitrios. "Laudationes Mulierum: Lives and Virtues of Five Exceptional Women".

Mommsen, Theodor. "Zwei Sepulcralreden aus der Zeit Augusts und Hadrians", $A A W B$ (1863), 455-489.

Mosaicarum et Romanarum Legum Collatio. With introduction, facsimile and transcription of the Berlin codex, translation, notes ad appendices by Rev. H. Hyamsom, Oxford University Press, 1913.

Osgood, Josiah. Turia: a Roman woman's Civil War. Oxford University Press, 2014.

Remains of Old Latin III: Lucilius, The Twelve Tables. Edited and translated by E.H. Warmington. London, Willian Heinemann ltd, Cambridge, Massachusetts, Harvard University Press, 1938.

Roman statutes. Vol. II. Ed. by M.H. Crawford. Institute of Classical Studies, School of Advanced Studies, University of London, 1996.

Select Papyri in Five Volumes: Non-literary papyri, private affairs, vol. I, with an English translation by A. S Hunt and C. C. Edgar, Published by William Heinemann / G. P. Putnam's Sons, 1932.

Select Papyri in Five Volumes: Non-literary papyri, public documents, vol. II, with an English translation by A. S. Hunt, published by Harvard / William Heinemann, 1934.

van Galen, Cornelis Willem. Women and Citizenship in the late Roman Republic and the early Empire. Radboud University Nijmegen, 2016.

Wallace-Hadrill, Andrew. "Family and Inheritance in the Augustan Marriage Laws", Proceedings of the Cambridge Philological Society. New Series, No. 27 (207), 1981, 58-80.

Watson, Alan. (ed.), The Digest of Justinian. I-IV vols. Philadelphia: University of Pennsylvania Press, 1985. 
